\title{
THE THEORY OF FORMS WITHOUT SUBSTANCE A ROMANIAN LEGAL TRANSPLANT THEORY AHEAD OF ITS TIME
}

Răzvan Cosmin Roghină

Lucian Blaga University of Sibiu, România, E-mail: razvan.roghina@ulbsibiu.ro

(Received: September 2020; Accepted: October 2020; Published: November 2020)

\begin{abstract}
Comparative law and legal history show us that law is dynamic, always in continuous development, change, or mutation. This dynamic dimension has become a central concern for the comparative law scholars. The circulation of legal models in the world (e.g. legal transplant, legal transfer, legal borrowing, legal migration) is an evergreen issue. This phenomenon has provoked numerous doctrinal disputes, which have been encapsulated in complex theories on its possibilities and impossibilities. In the present article, we will not explore the many modern theories regarding legal transplantation (or under other metaphors). Instead, we will go back in time, in the second half of the nineteenth century, to explore an interesting Romanian theory that seems to have anticipated a series of modern ideas regarding the purpose, possibilities, and impossibilities of the circulation of legal models in the world. Following this approach, the main conclusion will be resumed to the idea that the Romanian theory of forms without substance can be integrated within the modern theories of legal transplant.
\end{abstract}

Keywords: legal transplant, constitutional transplant, legal change, legal culture, forms without substance.

1. Forms without substance - an expression of the imbalance between social appearances and social content, between social capability and incapability

The theory of forms without substance ("Teoria formelor fără fond") has its ideological basis in the article "În contra direcţiei de astăzi în cultura română" (Against today's direction in the Romanian culture [1]) signed, in 1868, by T. Maiorescu (1840-1917). The mentioned theory developed controversy surrounding the cultural-artistic identity of the Romanian society. It emphasized the issues brought by the massive import that took place, in the nineteenth century, in all

\footnotetext{
* Corresponding author: Răzvan Cosmin Roghină.E-mail: razvan.roghina@ulbsibiu.ro

Copyright (C) 2020 The Author(s). Published by VGWU Press

This is an Open Access article distributed under the terms of the Creative Commons BY 4.0 license (Creative Commons - Attribution 4.0 International - CC BY 4.0) which permits unrestricted use,
} distribution, and reproduction in any medium, provided the original author and source are credited. 
areas of the Romanian social life. By doing so, the substance or content of the Romanian law was also discussed.

Regarding the name of the theory, it must be specified that its meaning was not marked by the specifics of the legal sphere, but by the general mirror of the Romanian society, hence the abstract character of the theory. The concrete features of the Romanian society were not highlighted and the imported legal mechanisms and legal institutions were not critically explored, in relation to what the Romanian social substance/ content could have offered. As a result, the linked terms form and substance were labels used to draw attention to the fact that between material (form) and spiritual or content (substance) there was another societal sphere that should not be ignored, i.e. the social binder, the social chain that holds them all together, in a coherent multi-layered social formula. In general, the substance was identified with the values, morals and mentalities of the people and less with socioeconomic or political elements [2].

T. Maiorescu's article determined many more similar analyses, i.e. the relationship between the Romanian culture (the substance) and the imported institutions (the forms). For example, reference was made to the fact that in 1866, the year when the first Romanian Constitution was adopted, the Belgian Constitution of 1831 was copied too faithfully [3], although the Romanian society could not compete with the level of development in the West. The massive constitutional import could not be ignored and, from certain points of view, not to be severely criticized.

The theory of forms without substance did not clarify technical aspects, e.g. indepth legal or political matters, but it had the merit of offering a modern perspective on legal transplant [4], in a context where the law should be understood through the prism of culture.

The idea that the forms should be organically supported or developed by the society was the core of the theory. The rupture - the empty gap - between the underdeveloped Romanian society and the borrowed Western modern forms built up the main object of discussion. The cause of the forms without substance was emphasized by T. Maiorescu, in the already mentioned article, as follows:

(...) our young people amazed by the great phenomena of modern culture, penetrated only the effects, they did not penetrate the causes, they saw only the forms above the civilization, they did not see the deeper historical foundations, which necessarily produced those forms... [5].

In concreto, the Romanian culture suffered because of those who, after studying in the West, returned and manifested internally as if they were part of the foreign politico-legal culture, embraced during their purely theoretical formation. The Romanian social background in which they wanted to imitate the forms that they had encountered and borrowed from the modern Western world was quite different. 
Roghină, R.C., (2020)

The consequence of this state of affairs consisted of irritating and, in time, frustrating the cultural identity of the Romanian society. Thus, as an expression, forms without substance sought to convey a general message related to the state of Romanian society: Western forms are far from the specifics of the Romanian social background. In other words, it indicated the imbalance that existed between the forms borrowed from the West and the Romanian cultural identity, i.e. the fact that the social background is not confused with the forms.

In the legal sphere of the debate, it was postulated that national law should be the image of the society; that it should be linked to organic social data and customs. The theory in the discussion did not rule out the possibility of encountering a successful social or legal transplant. It was only stated out that transplants are inopportune when ignoring the internal social links. This perspective can also be found in the modern theories regarding the legal transplant phenomena, such as those belonging to P. Legrand [6], A. Watson [7], E. Orrucu [8], G. Teubner [9].

\section{Exploring the theory of forms without substance - perspectives on the legal transplant}

The theoretical directions of the theory of forms without substance have taken into account, even if not at a very deep level, the interaction between law and society. From the analysis of this report, one can deduce the idea that law is mainly a natural product of society and that, consequently, it would be inappropriate to be blindly transplanted, because, as T. Maiorescu pointed out, it would weaken the social and legal identity of the host society [10]. Therefore, the evolution of law must take place, from a theoretical point of view, in sync with the cultural and economic development [11]. In other words, it was argued that the spirit, social, economic and political conditions behind the forms cannot be transplanted or at least not with a high degree of success. The indissoluble links between law and society impose the requirement of organic development. As a consequence, it would be pointless to transplant empty forms. Therefore, we may notice a series of ideas similar to those of P. Legrand [12].

However, how could a less developed society advance organically, at an acceptable pace, in order to become part of a certain desired modernity? On the road to finding an answer, it was observed that legal transplant should not be completely eliminated from the equation, but only conditioned. A base requirement was highlighted, i.e. that a transplant should take into account the specificity of the recipient's social, economic and political background, historically contextualized, in order not to cause irritation or rejection within the majority of the interpretative communities. If the irritation is too high or if the rejection is too profound, we witness a blitzkrieg process of emptying the forms of their substance. In other words, the state's social structures become artificial, a false reality. The forms 
shouldn't be, therefore, transplanted without any conscious internal evaluation. Thus, from the outright rejection of the legal transplant, it came to the acceptance of the positive contribution that it could have in the recipient law system. Even T. Maiorescu repositioned himself in this sense, acknowledging that sometimes legal transplant is necessary and can be beneficial if care is taken to match the transplant to specifics of to the receiver's social background [13] (compatibility test).

It was understood that Romania could not develop fat enough in the desired modern direction without new institutions. As stated, in order to avoid the installation of empty forms, it was necessary to harmonize the forms with the content or substance of the host society. Unfortunately, the latter has not been deeply or clearly identified by the Romanian critics. In order to proceed to a rational adaptation of the forms to the Romanian socio-political background, the substance of the Romanian social and legal identity should have been carefully determined and evaluated. Therefore, we may deduce the fact that the requirement of transposition, which we can find in E. Örücü's theory [14], was already part of the Romanian ideas about legal transplant.

For A.D. Xenopol (1847-1920), G. Ibrăileanu (1871-1936), C. Dobrogeanu Gherea (1855-1920) legal transplant was an instrument suitable to support the development of less evolved societies. For example, without ignoring the benefits of the organic development of societies, A.D. Xenopol argued that legal transplant was a normal consequence of the circulation of modern ideas in the world, of ideas that had proven to have a positive impact on many societies.

(...) Like all general human truths, these great principles are not the property of certain people. As each generation derives from others, so each people borrows them from another (...). The introduction of these principles into the life of a people, which does not yet enjoy them, is therefore a historical necessity, and a completely normal fact, based on the solidarity of peoples and their development in human history [15].

The Romanian historian concentrated more on the transplantation of ideas and less on the importation of institutions. He even considered that the transplant of institutions may not be beneficial. For him, a successful legal transplant was the one that managed to bring to the receiver society the ideas behind the institutions. The actors of the legal transplant, capturing the ideas of the forms - their logic could consequently carry out an assumed, coherent and, as an effect, a truly understood transplant.

The fundamental mistake of our political life, the mortal sin of our statesmen, was that they introduced not only the spirit of foreign settlements, but the settlements themselves in all their details (...). 
Roghină, R.C., (2020)

Not only the constitutional system has been introduced, namely the general principle of the people that must participate in the legiferation of the country and ensure its sovereignty, but also foreign laws have been introduced (...). The first step was good, the second was bad, destroying the good that the first could have produced and for what? Because the classes of our society and the ratio of significance in which they live, then the degree of culture and its division, are in our country quite different from the same circumstances in the countries from which we borrowed more or less those special laws [16].

On the other hand, G. Ibrăileanu believed in the capacity of the transplanted forms to provoke changes in the receiving society, where a critical transplant would be much more likely to bring about positive changes in the host society. The central idea of G. Ibrăileanu's thought was that legal import is inevitably meant to generate, develop, or create new cultural coordinates. For this, a socio-political effort was required to support the transplant [17]. At the same time, it was important to include in the transplantation equation not only the requirement to explore one's own system but also the judicious consideration and understanding of the (pre)selected foreign models.

As such, the opinion that legal transplant must be done in a rational formula has become quite a strong theses. It was underlined the fact that only through the prism of such a transplant could the difference between the receiver's cultural identity and the one sought to be gained through transplantation, on the one hand, and between one's own (living) identity and the one from which the forms were born and observed, on the other hand, be successfully harmonized. This is why the transplant should be performed in a critical spirit (G. Ibrăileanu) and the forms to be adapted to the host background [18] (transposition, as E. Orucu [19] would say). Adaptation was to serve for better interaction between form and substance, so as to encourage positive social and political changes.

The theory of forms without substance emphasized that the use of legal comparison can generate useful conclusions about the object, quantity of legal transplant, and, perhaps most importantly, with reference to the internal conditions that must exist or to be created in order to engage successful transplantation. Its success was deposited in the functioning of the receiving law system at the parameters of the donor system.

For some Romanian theorists and the Romanian political elite, it was obvious that the imported forms inevitably underwent changes, even when they were taken over with a high degree of fidelity. They concluded that it is sometimes possible for the host system to distort the forms so much that the finality of the legal transplant can no longer be recorded. The imported forms, being the product of another culture, carried the risk of not being understood by the interpretative communities of their new host system. T. Maiorescu also took into account these limits of knowledge. 
The theory of forms without substance. A romanian legal transplant theory ahead of its time

For example, he accounted the failure of the 1866 constitutional transplant [20] on the inability of the majority of the population to understand the transplanted informational baggage. This is true, but some critical emphasis should have been accounted for on the role of the political elite. The later also failed in their mission of implanting the internal finality of the Constitution: a representative government projected through the mechanisms of a dualist parliamentary regime [21]. Unfortunately, these issues related to the correct understanding of the institutions taken over from the Belgian Constitution did not enjoy systematic analyses. This action was necessary to be done, as the apparent changes caused by the transplanted forms proved to be in contradiction with the finality of the written content of the transplant and its teleological features. Their wrong application, as happened in the Romanian constitutional practice of the 19th century, compromised the desired outcome of the performed legal transplant. The success of a legal transplant must be conditioned under certain aspects, such as the type of the recorded effects. The transplanted forms may reshape - to some extend - or modulate the receiver's socio-political background and this goes the other way around. The host may modify the forms, but at the end of this process, it is important to still distinguish the nature and finality of the content of the transplant. If you undergo a legal transplant with the aim to infuse a representative political regime, the outcome - in terms of success - should be evaluated in the respective nature of the political regime aimed to be created and exercised. As such, we also believe that the degrees of success registered by a transplant must be retained through the lens of the finality of the transferred legal institutions and not by the simple retention that the forms have generated some (changes at the level of society. Such ideas can be deduced from the vision of M. Eminescu (1850-1889) regarding the imitation of forms and their interaction with the host society [22]. He noted that it is necessary to take measures to make the settlements (forms) a reality. They could only be alive if the functioned according to their purpose.

The advanced forms of higher civilizations, introduced as an exotic plant on our land, will have been inappropriate for us, but slowly and insistently the culture will be acclaimed and, from cosmopolitan, will become national [23].

Therefore, the effects triggered by foreign forms should not be criticized or rejected unconditionally. Referring to the Romanian constitutional transplant from 1866 , M. Eminescu managed to observe that the lack of effectiveness of the foreign forms was due, rather, to "those above".

(...) the parliamentary regime has become more and more vicious to us day by day, so that today the ministers have reached the position of being able to govern as they please, without control from below, without control from above. (...) there is no shadow of a doubt that a constitutional regime applied in such conditions is an 
Roghină, R.C., (2020)

The theory of forms without substance. A romanian legal transplant theory ahead of its time

illusion and nothing but an illusion, a deception, a keeping of pure external forms, a fiction (...). It is true that deceivers are also wrong; ministers deprived of any moral force are mistaken, because in vain they boast of those majorities in the Chamber, which in reality are only their own creations (...) There is no longer a relationship between the Crown and the people as between the legitimate will and legitimate aspirations because all mediating bodies are false. Parliament is a false creation of the minister, the will of the voter brought out by moral pressures, promises, decrees of promotions, and appointments is only a will squeezed in times of need and formulated according to the will of the minister...[24].

The forms were categorized as false because they had not received substance in practice. The defective representative governance, due to the speculative model in which the forms were put into practice, demonstrated the distortion of the spirit of the Constitution. The parliamentary regime did not work because the finality of the forms was compromised by the incapacities and interests of those who were fighting for political power. In addition, the Romanian political class formed an interpretive community incapable of properly managing the informational baggage behind the forms. Inevitably, the effect came to be the transgression of the constitutional settlements.

According to T. Rosetti (1837-1923), the failure of the transplanted forms found its causes in the Romanian society, insufficiently well developed to understand and handle the transplantation. The Romanian society became to possess empty and meaningless forms, a superficial civilization [25]. For T. Rosetti, the lack of adaptation of the forms and the absence of the original characters of the Romanian society from within the import equation were the reasons for the transplant failure.

By researching... all the institutions we have given ourselves so easily, with harsh criticism, we must force ourselves to remove everything that could not take root on our land, to change and develop in an original sense and adapted to the current degree of culture of the people, which will be shown to have vitality; to follow and bring to light everything that results from the daily needs, from the natural organization of our society, would have more right of existence than some abstract and misunderstood theory [26].

It may be noted that, in T. Rosetti's view, the host society was the one that, more quickly, irritated the forms, as it did not provide them with the necessary support. Even so, there are a number of ideas similar to those we find in the theory of "binding arrangements" of law with society, developed by G. Teubner. Cultural differences highlighted the need to form vivid links between substance and form. The unsatisfactory result was not due to the resistance from the Romanian society, but from its incapacities, respectively to the way in which the transplant was prepared and performed. The consequences of the irrational legal transplant, which 
The theory of forms without substance. A romanian legal transplant theory ahead of its time

did not take into account the cultural-legal specificity of the host, had to be taken into account.

Only looking at things as they are, only by researching in the historical antecedents and on the way forward, in cold blood and without passion the causes of the present state, only by turning to the observation of a fair proportion between the goals and the means at our disposal, will we enter a normal and progressive development [27].

However, unlike G. Teubner, T. Rosetti considered that a successful legal transplant was one that interacted with the cultural background of the host society, the one that managed to form links between form and substance. Also in the same range of law ties with society, C.D. Gherea evoked the fact that, although we had a system of legality, the country lived under a regime of illegality [28].

P.P. Carp also embraced this view. He attributed the negative social and political state of affairs to the political actors that introduced far too easily Western institutions and mechanisms that did not have in the Romanian society the necessary conditions to obtain roots.

When Romania, a bit of a virgin of any culture, suddenly found itself in front of the Western civilization, it was natural not to understand the whole mechanism and the whole course of this civilization; it was natural to often confuse cause with effect and to believe that by superficially imitating the effects, simply taking the forms which Western civilization used, we would arrive at the same result as Europe (...) [29].

P. Carp did not campaign for the elimination of foreign forms but rather demanded to truly exercise them, in order to really find out the capacity of the host. He also noted that foreign influences were the basis for the development of civilizations.

Let us take a retrospective look at the course of civilization, and I would ask you to show me in what part of history you have seen that a people has become educated, remaining only to its own strength: Nowhere will you find such a people. All other civilizations began with foreign roots [30].

Without abandoning the idea of organic development, P.P. Carp, like T. Maiorescu, gradually accepted the possibility for the forms to determine beneficial changes. If in November 1866 he firmly claimed that...

...we took the laws from foreign countries that had nothing to do with our state of affairs, and we did not even study if, in those countries from where we took the laws, they were not actually harmful (...)[31]...

...in 1895 he considered, using the records of history, that no society developed exclusively on its own, that evolution takes place through the assimilation of information. To some extent, we find the idea that tradition could mean 
Roghină, R.C., (2020)

The theory of forms without substance. A romanian legal transplant theory ahead of its time

information [32]. The social background could be perceived as sets of information. Information is the first step towards development.

(...) you want us to do what no nation in the world has done? New people, we are in the period of assimilation. And until this process of assimilating science, the experience of others, from us and through us, nothing serious will come out. Once we enter the European concern, in the whirlpool of modern culture, we either have to get to the level of this culture, or we have to disappear [33].

The task of activating the forms fell upon the political elite, which had to organize itself ideologically into truly formed political parties and then be able to contribute to social reorganization. Party struggles had to disappear and reforms had to be designed for the benefit of the country.

Even T. Maiorescu went so far from his original point of view - regarding the incapacity of the form to create substance - as to the point of stating that the fundamental law of 1866 had the power to bring useful changes, although he still evaluated it as a form without substance.

Besides, you have to conceive the Constitution as a school exercise for the people (...) it forces, in time, the people to reflect on themselves - because, from then on, they think so little - and it then allows more than another Constitution, the mature people to rise by their own powers? I think so [34].

A. Marghiloman (1854-1925), a believer of slow progress, without major leaps, admitted that sometimes society must be "helped", i.e the forms could contribute to the social development [35]. Within this scene of alternative views on the issue of forms and substance and their (re)creative power and incapacities, the position of G. Panu (1848-1910) should also be noted:

(...) to a social body you have to give broad forms in order to develop; its development is done in the power of organic vitality; over time, it fills the form that was first empty with the product of its activity, modifies it, cuts it, enlarges it (...) When we are told about the forms without substance, a very real process is overlooked. A background may not need a form, but a form needs a substance, and the form often brings the substance as well [36].

It was obvious to G. Panu that a transplanted law is subject to inevitable changes in the host's legal system. Transplantation, as a (re)creative tool, can serve progress, but the transplanted form, as A. Watson will argue in the 1970s, would not the same as in the previous house [37].

For E. Lovinescu, legal transplantation was the consequence of the need for cultural synchronization of less developed societies to the standards of those who represent modernity [38]. Under these conditions, for example, the massive Romanian constitutional transplant carried out in the middle of the 19 th century was completely justified. For the Romanian historian and literary critic, the success of a transplant was not necessarily limited to recording its 
Roghină, R.C., (2020)

The theory of forms without substance. A romanian legal transplant theory ahead of its time

finality. Lovinescu also assimilated for a successful transplant the idea of adapting the forms by the substance, to an extent that would reveal the expression of the host's originality. Like A. Watson, E. Lovinescu considered that in the world very few things are the result of one's own efforts, which is why the success or even the purpose of the transplant consisted of asserting one's own characters, as paradoxical as it sounds. The destiny of the transplanted law was understood in terms of the finality that the host gave it.

According to the Romanian public law professor P. Negulescu (1870-1951), the social background should create the substance of law encapsulated in the form [39]. He stated that law must be the mirror of society, with reference to the Constitution of 1866 .

The law is called to contain in rigid form, circumstances, state of affairs, habits, mentality, dominant ideas, in a word the state of civilization of the society to which it refers, for civilization is the result of life (...) the law cannot and must not be the creator of civilizations. It can only influence to some extent, in certain directions. But a law that can really be usefully and lasting can only be one that corresponds to public opinion, to the situation that existed at that time. When a law does not correspond to the factual situations to which it applies, when it does not respond to a need of that moment, it risks being left without application [40].

The emphasis was put on the reality/ realism of the Romanian society and the later did not correspond to the one outlined in the Constitution of 1866. By ignoring the differences between the specific/ spirit of the society and the applied law, the transplanted forms can be severely distorted and, as a result, negative consequences may arise [41].

The Constitution of 1866, in view of our state of civilization at that time, appears to us as a garment far too loose for the one who is to wear it [42].

The timing of the constitutional transplant could have been controlled by choosing a model closer to the capacity of the host - one that would have provided a more suitable and, thus, sustainable development model for the Romanian society. Negulescu's ideas do not reject the usefulness of legal transplantation, but rather disapprove a certain type of legal transplant, i.e. the one made from where and when a certain society should not perform such an act. A transplant performed in such circumstances could only be "unreal" in its application. Negulescu's ideological vision can be placed between G. Teubner's theory of legal irritation and P. Legrand's theory on the impossibility of legal transplants. The Constitution of 1866 projected a reality and the Romanian system a completely different one. According to P. Negulescu, the authoritarian regime was the only reality that would have identified both with the specifics of the Romanian society and with the 
Roghină, R.C., (2020)

The theory of forms without substance. A romanian legal transplant theory ahead of its time

possibilities of applying the law. Therefore, the parliamentary regime projected by the 1866 fundamental law was nothing but a mere mirage.

\section{Conclusions}

The theory of forms without substance provided a critical manifesto on the phenomenon of legal transplant. It pointed out that a constitutional transplant must be based not only on subjective reasons, such as the weakness of domestic law (lack of own resources), but also objective circumstances, such as the conclusions of a rational comparative exercise between the donor and the receiver. It is important to have a balance between them. Of course, a more passionate critical voice would build ascendancy on the objective impulses over subjective ones.

For the success of the transplant, it can be decisive to rationally consider its circumstances, i.e. when, how, from where and how much. Taking into account the social reality of the Romanian socio-political background, the general conclusion of the theory of forms without substance is that the forms cannot be unconditionally the dynamic factors of change. These must be supported by the interpretive communities in the field of law and beyond.

Having in mind the underlined idea extracted from the theory of forms without substance, we can state that fact that the discussed theory can be righteously integrated into the modern theories of legal transplant.

\section{Acknowledgments}

The author thanks the anonymous reviewers and editor for their valuable contribution.

\section{Funding}

This research received no specific grant from any funding agency in the public, commercial, or not-for-profit sectors.

\section{Author Contributions}

The entire article was written by Răzvan Cosmin Roghină.

\section{Disclosure Statement}

The author has not any competing financial, professional, or personal interests from other parties.

\section{References}

1. Carp P., (1879). Discurs privind articolul 7 din Constituție (28 septembrie 1879). In Stanomir, I., Vlad, L. (2002). A fi conservator (pp. 81-83), București: Meridiane.

2. Drăganu, T., (1991), Începuturile şi dezvoltarea regimului parlamentar în România, pană la 1916, Cluj-Napoca: Editura Dacia;

3. Eminescu, M., (1984). Opere, Vol. XII, București: Editura Academiei RSR; 
Roghină, R.C., (2020)

The theory of forms without substance. A romanian legal transplant theory ahead of its time

4. Eminescu, M.. (2002). Influența austriacă asupra românilor din Principate. In Stanomir, I., Vlad, L. (2002). A fi conservator (pp. 95-96), București: Meridiane;

5. Glenn, P., (2001). Are legal Traditions Incommensurable?, The American Journal of Comparative Law, Vol. 49, no. 1, pp. 133-145;

6. Guțan, M., (2009). Dreptul comparat contemporan și actualitatea teoriei ,formelor fără fond", Pandectele Române, no. 4, pp. 39-67.

7. Guțan, M., (2013). Transplant constituțional și constituționalism în România modernă 1802-1866, București, Romania: Hamangiu.

8. Ibrăileanu, G., (1970). Spiritul critic în cultura română, Iași: Junimea;

9. Legrand, P., (1995). Legal Traditions in Western Europe: the Limits of Commonality. In R. Jagtenburg, E. Örücü, A. de Roo (Ed.), Transfrontier Mobility of law, Haga: Kluwer Law International.

10. Legrand, P., (1996). European Legal Systems are not Converging, International Comparative Law Quarterly, Vol. 45, no. 1, pp. 52-81;

11. Legrand, P., (1997). The Impossibility of „Legal Transplants”, Maastricht Journal of European and Comparative Law, Vol. 4, pp. 111-124.

12. Lovinescu, E., (1997). Istoria civilizaţiei române moderne, București: Minerva.

13. Maiorescu, T., (1978). Opere, I, București, Romania: Minerva.

14. Negulescu, P., (1927). Curs de drept constituţional, Bucureşti.

15. Örücü, E., (2002). Law as Transposition, International and Comparative Law Quarterly, Vol. 51, pp. 205-223;

16. Roghină, R.C., (2016). Logica și efectele transplantului constituţional din 1866, București, Romania: Universul Juridic.

17. Rosetti, T., (2002). Despre direcțiunea progresului nostru, In I. Stanomir, L. Vlad (2002), A fi conservator (p. 73), București: Meridiane.

18. Schifirneț, C., (2007). Formele fără fond. Un brand românesc, București, Romania: Comunciare.ro.

19. Teubner, G., (1998). Legal Irritants, Modern Law Review, Vol. 11, pp. 11-32.

20. Watson, A., (1976). Legal Transplants and Law Reform, Law Quarterly Review, 92, no. 1, pp. $79-84$.

21. Watson, A. (1982-1983). Legal Change: Sources of Law and Legal Culture, University of Pennsylvania Law Review, Vol. 131, no. 5, p. 1121-1157;

22. Watson, A., (1987). Evolution of Law: Continued, Law and History Review, Vol. 5, pp. 537-570.

23. Watson, A., (2001). Legal History and Common Law for Europe, Mystery, Reality, Imagination, Stockholm: Arne Longfern Offset AB.

24. Xenopol, A.D., (2002). Despre reforma așezămintelor noastre, In Stanomir, I., Vlad, L. (2002). A fi conservator (pp. 58-59), București: Universitatea din București, Institutul de cecetări politice, Meridiane.

\section{Notes}

[1] My translation from Romanian. 
Roghină, R.C., (2020)

[2] C. Schifirneț, Formele fără fond. Un brand românesc, Comunciare.ro, București, pp. 55et. seq..

[3] See R.C. Roghină, Logica și efectele transplantului constituțional din 1866, Universul Juridic, București, 2016, pp. 179-204; M. Guțan, Transplant constituțional și constituționalism în România modernă 1802-1866, Hamangiu, București, 2013, pp. 354359.

[4] On the actuality of the Romanian theory of forms without substance, see also M. Guțan, Dreptul comparat contemporan și actualitatea teoriei „formelor fără fond”, Pandectele Române, no. 4, 2009, pp. 39-67.

[5] My translation from Romanian. For the original text, see T. Maiorescu, Opere, I, Minerva, București, 1978, pp. 147-148.

[6] Legal Traditions in Western Europe: the Limits of Commonality, în „Transfrontier Mobility of law", R. Jagtenburg, E. Örücü, A. de Roo (eds.), Kluwer Law International, Haga, 1995; Idem, European Legal Systems are not Converging, International Comparative Law Quarterly, Vol. 45, no. 1, 1996, pp. 52-81; Idem, The Impossibility of „Legal Transplants", Maastricht Journal of European and Comparative Law, Vol. 4, 1997, pp. 111124.

[7] A.Watson, Legal Transplants and Law Reform, Law Quarterly Review, Vol. 92, no. 1, 1976, p.79; Idem, Legal Change: Sources of Law and Legal Culture, University of Pennsylvania Law Review, Vol. 131, no. 5, 1982- 1983, p. 1152; Idem, Evolution of Law: Continued, Law and History Review, Vol. 5, 1987, pp. 537-570.

[8] E. Örücü, Law as Transposition, International and Comparative Law Quarterly, Vol. 51, 2002.

[9] G. Teubner, Legal Irritants, Modern Law Review, Vol. 11, 1998, pp. 11-32.

[10] This idea was also stated by P. Carp (1837-1919). See, P. Carp, Discurs privind articolul 7 din Constituție (28 septembrie 1879), in I. Stanomir, L. Vlad, A fi conservator, Meridiane, București, 2002, pp. 81-83.

[11] T. Maiorescu, Opere... cit., p. 473.

[12] See P. Legrand, The Impossibility of „Legal Transplants”...cit., pp. 111 et. seq.

[13] C. Schifirneț, Formele fără fond... cit., pp. 73 et. seq..

[14] E. Örücü, Law as Transposition... cit..

[15] My translation from Romanian. For the original text, see, A.D. Xenopol, Despre reforma așezămintelor noastre, in I. Stanomir, L. VLad, A fi conservator, Universitatea din București, Institutul de cecetări politice, Meridiane, București, 2002, pp. 58-59.

[16] My translation from Romanian. For the original text, see Ibid, p. 59.

[17] G. Ibrăileanu, Spiritul critic în cultura română, Junimea, Iași, 1970.

[18] C. Schifirneț, Formele fără fond... cit., p. 113.

[19] E. Örücü, Law as Transposition... cit..

[20] R. C. Roghină, Logica și efectele... cit., pp. 356 et. seq..

[21] Ibid, pp. 260 et. seq..

[22] See, M. Eminescu, Opere, Vol. XII, Edit. Academiei RSR, București, 1984, pp. 55, 267, 277, 321.

[23] My translation from Romanian. For the original text, see Ibid, p. 332. 
Roghină, R.C., (2020)

The theory of forms without substance. A romanian legal transplant theory ahead of its time

[24] My translation from Romanian. For the original text, see M. Eminescu, Influența austriacă asupra românilor din Principate, in I. Stanomir, L. Vlad, A fi conservator... cit., pp. 95-96.

[25] T. Rosetti, Despre direcțiunea progresului nostru, in Ibid, p. 73.

[26] My translation from Romanian. For the original text, see, Ibid, p. 74.

[27] My translation from Romanian. For the original text, see, Ibid, p. 75.

[28] C. Schifirneț, Formele fără fond... cit., p. 114.

[29] My translation from Romanian. For the original text, see Ibid, p. 130.

[30] My translation from Romanian. For the original text, see Ibid

[31] My translation from Romanian. For the original text, see, Ibid

[32] For the development of this issue, see H.P. Glenn, Are legal Traditions Incommensurable?, The American Journal of Comparative Law, Vol. 49, no. 1, 2001, pp. 133-145.

[33] My translation from Romanian. For the original text, C. Schifirneț, Formele fără fond... cit., p. 131.

[34] My translation from Romanian. For original text, see T. Maiorescu, Însemnări zilnice, vol. I (1855-1880), Socec \& Co, Bucureşti,1937, p. 132.

[35] T. Drăganu, Începuturile şi dezvoltarea regimului parlamentar în România, pană la 1916, Edit. Dacia, Cluj-Napoca, 1991, pp. 356-357.

[36] My translation from Romanian. For original text, see Ibid, p. 357.

[37] A. Watson, Legal History and Common Law for Europe, Mystery, Reality, Imagination, Arne Longfern Offset AB, Stockholm, 2001.

[38] E. Lovinescu, Istoria civilizaţiei române moderne, Minerva, Bucureşti, 1997, pp. 352353.

[39] P. Negulescu, Curs de drept constituţional, Bucureşti, 1927, pp. 221-225.

[40] My translation from Romanian. For original text, see Ibid, p. 221.

[41] My translation from Romanian. For original text, see Ibid, p. 225.

[42] My translation from Romanian. For original text, see Ibid, p. 221. 